\title{
Efikasi Diri Mahasiswa Memulai Berwirausaha
}

\author{
HADIYATI \\ Universitas Lancang Kuning \\ Jln. Yos Sudarso Km 08 Rumbai Telp. (0761) 52581 Fax. (0761) 52581 \\ E-mail : hadiyati@unilak.ac.id
}

\begin{abstract}
The real manifestation in learning entrepreneurship is the emergence of confidence or confidence that students have to start a business. However, from the pre-survey conducted, only about less than $10 \%$ of students had confidence in entrepreneurship. Of course there are many factors that cause it both internal factors and student external factors. So this study wants to know the determinant model of self-confidence in entrepreneurship students. This information is important to know because it is a basis for evaluating the development of young student entrepreneurs. The use of syntheses from various theories of entrepreneurial student self-confidence and the testing of hypotheses from theory used as the basis of this model's research. The method used is survey research with a quantitative approach. Data was collected from the student population of semester VI and VIII with a sample of 88 students. Data collection using online questionnaires and data analysis techniques using quantitative analysis techniques with structural equation modeling (SEM) analysis with the support of WarpPLS software. The results showed that of the five variables that were thought to affect students' self-efficacy in entrepreneurship had an influence of $36 \%$ and it turned out that from five variables such as: Successful experience, lived events, verbal persuasion and physiological and mood conditions and interpersonal communication skills proved to be only three variables which has a significant effect on successful experience, lived events and communication skills. Whereas the rest, such as verbal persuasion and moods, do not have a significant effect and it turns out that the most influential is successful experience and communication skills. It is evident that it is proven that self-efficacy (self-confidence) in student entrepreneurship has a significant effect on the interest in business entrepreneurship, which is $48 \%$.
\end{abstract}

Keywords: Self Efficacy, Entrepreneurship Interest, Successful Experience, Live Events, Verbal Persuasion and Mood and Communication Skills

Kewirausahaan menjadi bagian penting dalam rangka mengatasi berbagai persoalan ekonomi yang ada dalam sebuah Negara. Melalui pengembangan kewirausahaan, banyak manfaat diperoleh diantaranya adanya perkembangan produk kreatifitas yang dihasilkan wirausahawan dan juga terciptanya lapangan pekerjaan yang menjadi bagian penting dan juga solusi bagi pemerintah dalam rangka mengurangi angka pengangguran. Kemudian juga masalah daya saing bangsa yang dengan wirausahawan generasi muda dapat menjadi bangsa yang mandiri dengan tingkat daya saing yang tinggi.

Kemampuan sebuah bangsa untuk bertahan dan tumbuh berkembang menjadi Negara yang berdaulat dan bangsa yang mandiri menjadi sebuah cita-cita berdirinya sebuah bangsa. Bangsa yang memiliki sumberdaya manusia yang handal dengan kreatifitasnya menghasilkan inovasi sangat membantu dalam mewujudkan keinginan bangsa dan juga sangat menjadi solusi dari berbagai masalah yang dihadapi sebuah bangsa. Bahkan sebagaimana bangsa Indonesia saat ini sudah menjadikan kajian kewirausahaan menjadi kajian strategis untuk diprioritaskan guna mencapai apa yang diharapkan.

Perguruan tinggi sebagai salah satu agen perubahan bangsa menjadikan para generasi penerus bangsa menimba ilmu dan pengetahuan serta teknologi guna siap menghadapi persaingan yang ketat dengan bangsa lain. Perguruan tinggi dengan berbagai keunikannya dan sumber daya 
yang mampu menjawab berbagai persoalan yang dihadapi bangsa, akan menjadikan perguruan tinggi sebagai lembaga yang strategis merubah cara pandang generasi muda.

Generasi muda yang aktif dan juga memiliki rasa ingin tahu yang tinggi akan sangat tertantang dengan berbagai kondisi yang ada dan bahkan melalui berbagai guncangan masa depan juga siap untuk dihadapinya. Generasi muda membutuhkan nutrisi pengetahuan, kemampuan berpikir kritis, ketrampilan hidup dan juga berbagai kebutuhan sikap dan prilaku yang seharusnya mereka akan dapatkan di lembaga pendidikan. Generasi muda berupa mahasiswa adalah generasi muda terkini yang siap bersaing menghadapi kondisi nyata di masa depan.

Persaingan yang ketat pada dunia usaha menjadikan lembaga perguruan tinggi harus bersinerji dengan selalu menyusun kurikulum yang siap untuk menghadapi bebagai keadaan yang dibutuhkan di masa depan. Sinerji dengan dunia bisnis, sinerji dengan orang tua dan sinerji dengan mahasiswa serta pemerintah menjadikan lembaga perguruan tinggi dapat menawarkan menu yang unik bagi mahasiswa. Persiapan lembaga tersebut dengan matang dipersiapkan, mulai dari tenaga pendidik yang berpengalaman dan juga berpengetahuan dibidangnya ditambah dengan kelengkapan sarana dan prasarana penunjang pendidikan dan sistem pendidikan yang siap pakai dan juga berbagai dukungan kerjasama dengan dunia usaha akan menjadikan lembaga dapat menjawab persoalan masa depan.

Sebagaimana yang dipersiapkan oleh Prodi Manajemen Universitas Lancang Kuning. Saat ini dengan pengembangan kurikum berbasis KKNI dan dengan bersinerji dengan dunia usaha dan juga memiliki learning outcome wirausaha muda dan manajer lini pertama menjadikan Prodi Manajemen selalu harus mengevaluasi diri, melihat perkembangan mahasiswa dan juga selalu memahami kendala yang dialami dan juga melakukan perbaikan dari masa ke masa.

Permasalahan intensi berwirausaha mahasiswa semester lima dan tujuh, dimana mahasiswa yang sudah diberikannya berbagai pengetahuan dan juga ketrampilan serta motivasi berwirauaha, sudah semestinya menghasilkan mahasiswa yang memiliki efikasi diri mahasiswa berwirausaha. Namun dari hasil pra survey yang dilakukan kepada 30 orang mahasiswa, diketahui bahwa kurang dari 10\% mahasiswa Prodi. Manajemen memiliki efikasi diri yang tinggi dalam berwirausaha. Sedangkan sisanya mahasiswa masih ragu dan bahkan kurang memiliki efikasi diri untuk berwirausaha.

Terdapat banya faktor determinan efikasi diri mahasiswa berwirausaha, diantaranya sebagaimana disampaikan oleh Bandura dalam Rustika, I. M. (2012) bahwa efikasi diri dipengaruhi oleh pengalaman individu yang berhasil mencapai tujuannya, Kejadian orang lain yang dihayati oleh individu seakan dialami pada diri sendiri, persuasi verbal dalam diri dan suasana hati diri sendiri. Hal serupa juga disampaikan oleh Wulandari, S. (2013) yakni variabel pengalaman menyelesaikan masalah, pengalaman pengganti, persuasi verbal dan keadaan fisiologis. Jugas disampaikan oleh Adicondro (2011) bahwa efikasi diri dipengaruhi oleh pengalaman menguasai sesuatu prestasi, pengalaman vikarius, persuasi sosial dan pembangkitan emosi. Selanjutnya faktor lainnya juga dijelaskan oleh Suseno (2012) bahwa tambahan variabel melatih komunikasi interpersonal dapat meningkatkan efikasi diri.

Sedangkan efikasi diri ini akan memberikan dampak kepada minat berwirausaha, sebagaimana disampaikan oleh Evaliana, Y. (2015) dan juga disampaikan oleh Kadarsih, R., \& Sumaryati, S. (2013) dan juga pendapat Anggraeni, D. A. L., \& Nurcaya, I. N. (2016) serta pendapat Wijaya, T. (2009). 
Berangkat dari pendapat tersebut, maka apakah pengalaman individu yang berhasil mencapai tujuannya, Kejadian orang lain yang dihayati oleh individu seakan dialami pada diri sendiri, persuasi verbal dalam diri dan suasana hati diri sendiri memberikan pengaruh pada efikasi mahasiswa berwirausaha dan berdampak pada minat berwirausaha.

Uraian pada latar belakang dapat dijadikan dasar untuk dirumuskan masalah dalam penelitian ini yakni berkaitan dengan efikasi diri atau rasa percaya diri para pemula khususnya mahasiswa dalam memulai usahanya. Sebagaimana dijelaskan oleh Bandura dalam Rustika, I. M. (2012) bahwa rasa percaya diri yang lebih dikenal dengan istilah efikasi merupakan bentuk sebuah keyakinan seseorang untuk mencapai apa yang dimaksudnya. Untuk mencapai sebuah tujuan butuh kepercayaan diri yang tinggi, sebab apabila tidak dimiliki rasa percaya diri maka akan berdampak kepada ketidaktercapaian tujuan tersebut. Selanjutnya Bandura juga menjelaskan bahwa terdapat tiga dimensi yang digunakan dalam mengukur rasa percaya diri tersebut antara lain: pertama adalah tingkat kesulitan atau magnitude yang berkaitan dengan masalah kesungguhan yang dimiliki untuk menghadapi tantangan yang dicapai walaupun banyak cobaannya dan kedua adalah kekuatan atau strenght yaitu berkaitan dengan kuat adanya kekuatan dalam diri dan kekuatan luar diri yang siap digunakan untuk menghadapi tantangan tersebtu dan yang ketiga adalah generality sebuah kondisi dimana seorang dapat yakin bahwa tujuan tersebut mampu dicapainya.

Selain itu juga Bandura menjelaskan bahwa terdapat empat faktor yang menentukan keberhasilan efikasi diri seseorang dalam mencapai tujuannya antara lain: pertama pengalaman individu dalam menyelesaikan sebuah masalah, kedua pengalaman orang lain yang berhasil mencapai tujuannya, ketiga adalah persuasi verbal, keempat adalah keadaan emosional diri dan kelima adalah suasana hati seseorang. Kelima variabel tersebut menjadi sebuah gambaran yang akan diuji kebenarannya dalam penelitian ini dimana dalam kasus efikasi diri mahasiswa apakah kelima variabel tersebut memberikan pengaruh yang nyata dalam berwirausaha.

Sebelumnya menurut Yanto dalam Christers (2010) perlu dijelaskan makna kewirausahaan, dimana wirausaha adalah keberanian seseorang untuk mencapai tujuan baik kebutuhan, bisnis maupun kekuatan dalam diri. Sedangkan, Santoso (1993) kewirausahaan adalah keadaan dalam diri seseorang dalam berusaha yang berbentuk sifat dan sikap yang ada dan digunakan dalam berwirausaha.

Karena kewirausahaan adalah sikap, maka Sumarwan (2003) menjelaskan untuk mengukur sikap wirausaha dapat digunakan komponen berikut: pertama komponen kognitif, kemudian konatif dan psikomotor.

Menurut Walgito (2003) keadaan fisik sangat menentukan seseorang berwirausaha. Selain itu juga faktor psikis juga demikian. Dengan demikian dapat diketahui dengan jelas bahwa diduga faktor determinan yang mempengaruhi efikasi diri atau percaya diri mahasiswa memulai usaha adalah pengelaman berhasil, pengalaman orang lain, kondisi dalam diri, persuasi verbal dan suasana hati.

\section{METODE}

Penelitian jenis survey dengan pendekatan kuantitatif digunakan dalam penelitian ini. Penelitian yang melakukan uji hipotesis penelitian dengan menggunakan hipotesis statistik sebagai bahan penguji yang ada.

Data yang digunakan berbentuk data primer dan data skunder, dapat dilihat dari uraian berikut ini: Data primer, Berisikan data yang langsung diperoleh dari responden penelitian diantaranya dapat tanggapan responden tentang pengalaman individu yang berhasil mencapai tujuannya, Kejadian orang lain yang dihayati oleh 
individu seakan dialami pada diri sendiri, persuasi verbal dalam diri dan suasana hati diri sendiri, efikasi diri dan minat mahasiswa berwirausaha. Data sekunder, Berisikan data yang berasal dari Prodi. Manajemen berkaitan dengan perkembangan jumlah mahasiswa dan juga gambaran mahasiswa.

Penelitian ini menggunaan objek penelitian adalah mahasiswa aktif program studi manajemen (S1) semester VI dan VIII Universitas Lancang Kuning, dengan jumlah 710 orang. Sampel diambil sebanyak 88 orang secara cluster random sampling

Perhitungan Sampel:

$$
\begin{aligned}
& \mathrm{n}=710 / 710 \times 10 \%^{2}+1 \\
& \mathrm{n}=710 / 8,10 \\
& \mathrm{n}=88
\end{aligned}
$$

Penelitian ini dilakukan di Prodi Manajemen (S1) Universitas Lancang Kuning, Proses penelitian dilakukan selama 5 Bulan yaitu bulan April 2019 - Agustus 2019. Data dikumpulkan dengan menggunakan kuesioner online.

Penelitian ini menggunakan metode kuantitatif. Pengolahan data dimulai dari memperhitungkan secara deskriptif masingmasing variabel penelitian. Jawaban responden diberikan skore dengan menjumlahkan perkalian bobot masingmasing jawaban dengan frekuensi jawaban responden lalu dibagi dengan sampel penelitian. Data dianalisis dengan menggunakan WarPLS dengan model SEM.

\section{HASIL}

Berdasarkan hasil survey secara online berkenaan dengan variabel penelitian. Bahwa rata-rata jawaban responden terhadap variabel minat berwirausaha 4,14 yang masuk dalam kategori baik. Ini menunjukkan bahwa mahasiswa memiliki minat berwirausaha yang baik selama ini. Dari tiga item yang ditanyakan ternyata item tertinggi jatuh pada keingintahuan dalam berwirausaah. Sedangkan item terendah jatuh pada masih belum memiliki rencana yang mantap dibuat selama kuliah.

Kemudian jawaban responden terhadap variabel efikasi diri mahasiswa Program studi manajemen dalam berwirausaha dapat dilihat bahwa efikasi diri mahasiswa dalam berwirausaha dengan bobot 4,08 masuk dalam kategori baik. Dimana mahasiswa memiliki rasa percaya diri yang tinggi dalam berwirausaha. Dari 3 item yang ditanyakan dapat diketahui bahwa item tertinggi terletak pada kesiapan menghadapi tantangan masa depan dan item terendah terletak pada masih rendahnya rasa percaya diri dalam berwirausaha.

Selanjutnya tanggapan responden terhadap variabel pengalaman berhasil yang dimiliki mahasiswa dapat dilihat bahwa jawaban responden terhadap pengalaman berhasil dalam berwirausaha yang dimiliki mahasiswa dengan rata-rata skor 3,92, masuk dalam kategori baik. Ini menunjukkan bahwa mahasiswa sudah memiliki pengalaman berhasil dalam mencoba beberapa hal untuk berwirausaha. Dari 3 item yang ditanyakan dapat diketahui bahwa jawaban tertinggi terletak pada senang membaca kisah sukses pengusaha dalam berwirausaha sedangkan jawaban terendah terletak pada memiliki keluarga yang berhasil dalam berwirausaha. Dilanjutkan pada variabel kejadian yang dihayati, dapat dilihat dari uraian bahwa jawaban responden dengan rata-rata skor seesar 4,13 masuk dalam kategori baik. Ini menunjukkan bahwa kejadian yang dihayati dari program studi manajemen seperti dalam kegiatan perkuliahan dan juga kesempatan untuk mengembangkan diri dalam bidang kewirausahaan juga diberikan kepada mahasiswa. Untuk lebih jelasnya dapat dilihat berkenaan dengan variabel kejadian yang dihayati dengan skor 4,13 masuk dalam kategori baik dan ini apabila dilihat dari 3 item yang ditanyakan item tertinggi adalah pada tidak mudah putus asa dalam mencoba dan menghadapi kegagalan sedangkan item terendah adalah pada masih belum merasa memahami bagaimana rasanya berwirausaha sehingga masih butuh pengalaman.

Terakhir deskripsi tentang variabel persuasi verbal mahasiswa, dari jawaban responden dapat dilihat bahwa jawaban responden terhadap persuasi verbal yang 
dimiliki dengan skor 4,20 masuk dalam kategori baik. Hal ini menunjukkan bahwa pada dasarnya mahasiswa manajemen sudah memiliki kemampuan berbicara dan menawarkan produknya kepada pasar atau calon konsumen. Dari 3 item yang ditanyakan dapat diketahui bahwa item tertinggi terletak pada senang berkomunikasi dengan orang banyak dan banyak teman, sedangkan terendah adalah pada masih kurang memiliki kemampuan meyakinkan orang lain.

Kemudian jawaban responden terhadap variabel suasana hati mahasiswa Program studi manajemen dapat dilihat bahwa suasana hati mahasiswa dalam belajar kewirausahaan dengan bobot 4,04 masuk dalam kategori baik. Dimana mahasiswa memiliki suasana hati yang baik. Dari 3 item yang ditanyakan dapat diketahui bahwa item tertinggi terletak pada tidak mudah marah dalam menghadapi perbedaan dan item terendah terletak pada masih terburu-buru dalam mengambil keputusan.

Kemudian jawaban responden terhadap variabel ketrampilan berkomunikasi mahasiswa Program studi manajemen dapat dilihat bahwa ketrampilan berkomunikasi mahasiswa dalam belajar kewirausahaan dengan bobot 4,29 masuk dalam kategori sangat baik. Dimana mahasiswa memiliki kemampuan dalam berkomunikasi baik secar verbal maupun non verbal. Dari 3 item yang ditanyakan dapat diketahui bahwa item tertinggi terletak pada senang berdiskusi sesama rekan dan item terendah terletak pada masih mudah tersingguh dari adanya perbedaan sesama teman.

Analisis Pengaruh Pengalaman berhasil, kejadian yang dihayati, persuasi verbal dan keadaan fisiologis dan suasana hati serta ketrampilan komunikasi interpersonal Terhadap Efikasi Diri Mahasiswa dan Dampaknya pada Minat Berwirausaha Mahasiswa

Dari hasil analisis data dengan menggunakan alat analisis SEM, dan data diolah dengan mengguankan software WarpPLS, maka dapat full model penelitian dapat dilihat dari gambar berikut ini;

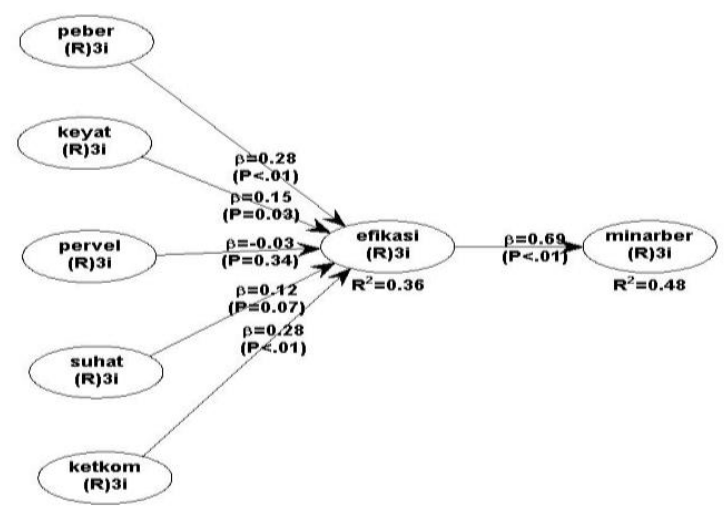

Gambar 1:

Full Model Faktor Determinan Efikasi Diri Mahasiswa Berwirausaha

Dari gambar tersebut dapat diketahui bahwa lima variabel yang diduga mempengaruhi efikasi diri mahasiswa dalam berwirausaha memiliki pengaruh sebesar 36\% dan ternyata dari kelima variabel seperti: Pengalaman berhasil, kejadian yang dihayati, persuasi verbal dan keadaan fisiologis dan suasana hati serta ketrampilan komunikasi interpersonal terbukti hanya tiga variabel yang berpengaruh signifikan yakni pengalaman berhasil, kejadian yang dihayati dan ketrampilan berkomunikasi. Sedangkanya sisanya seperti persuasi verbal dan juga suasana hati tidak berpengaruh signifikan dan ternyata yang paling besar pengaruhnya adalah pengalaman berhasil dan ketramplan berkomunikasi.

Selain itu juga terbukti bahwa efikasi diri (rasa percaya diri) berwirausaha mahasiswa berpengaruh signifikan terhadap minat berwirausaha usaha yakni pengaruhnya sebesar $48 \%$.

\section{PEMBAHASAN}

Dari uraian tersebut, dapat dengan jelas diketahui bahwa sebagaimana dijelaskan pada penelitian yang dilakukan sebelumnya yakni minat berwirausaha usaha mahasiswa itu dipengaruhi oleh intensi berwirausaha usaha, juga terbukti 
dipengaruhi oleh efisikasi diri mahasiswa itu sendiri. Dimana mahasiswa yang memiliki rasa percaya diri yang tinggi khususnya dalam hal pengalaman yang dimilikinya pada hal-hal yang berhasil dan mendengarkan dan membaca kisah berhasil orang atau pengusaha terdahulu dan juga dalam hal kemampuan yang dimilikinya dalam berkomunikasi berpngeruh signifikan terhadap minat berwirausaha mahasiswa.

Hal ini membuktikan pendapat penelitian sebelumnya yakni Bimo Walgito (2003) dan juga Bandura dalam Rustika, I. M. (2012) yang memberikan pandangan sama, namun memang adanya perbedaan yang menonjol dalam penelitian ini yakni ternyata variabel suasana hati dan juga persuasi verbal tidak berpengaruh signifikan dan bahkan persuasi verbal dan kondisi fisiologis malahan berpengaruh negatif namun tidak signifikan dalam membangun rasa percaya diri mahasiswa dalam berwirausaha.

\section{SIMPULAN}

Berdasarkan hasil penelitian yang dilakukan di lapangan maka dapat ditarik beberapa kesimpulan sebagai berikut: Terbukti dari lima variabel yang diduga mempengaruhi efikasi diri mahasiswa dalam berwirausaha memiliki pengaruh sebesar $36 \%$ dan ternyata dari kelima variabel seperti: Pengalaman berhasil, kejadian yang dihayati, persuasi verbal dan keadaan fisiologis dan suasana hati serta ketrampilan komunikasi interpersonal terbukti hanya tiga variabel yang berpengaruh signifikan yakni pengalaman berhasil, kejadian yang dihayati dan ketrampilan berkomunikasi. Sedangkanya sisanya seperti persuasi verbal dan juga suasana hati tidak berpengaruh signifikan dan ternyata yang paling besar pengaruhnya adalah pengalaman berhasil dan ketramplan berkomunikasi.

Terbukti bahwa terbukti bahwa efikasi diri (rasa percaya diri) berwirausaha mahasiswa berpengaruh signifikan terhadap minat berwirausaha usaha yakni pengaruhnya sebesar $48 \%$.

\section{DAFTAR RUJUKAN}

Adicondro, N., \& Purnamasari, A. (2011). Efikasi diri, dukungan sosial keluarga dan self regulated learning pada siswa kelas VIII. Universitas Ahmad Dahlan.

Alwisol. 2004. Psikologi Kepribadian. Malang: UMM Press.

Anggraeni, D. A. L., \& Nurcaya, I. N. (2016). Peran Efikasi Diri Dalam Memediasi Pengaruh Pendidikan Kewirausahaan Terhadap Niat Berwirausaha. E-Jurnal Manajemen Universitas Udayana, 5(4).

Bandura, Albert. 1977. Self Efficacy Toward a Unfying Theory of Behavioural Change. Journal of Phycological Vol. 84, No.2.

Evaliana, Y. (2015). Pengaruh efikasi diri dan lingkungan keluarga terhadap minat berwirausaha siswa. JPBM (Jurnal Pendidikan Bisnis dan Manajemen), 1(1), 53-60.

Kadarsih, R., \& Sumaryati, S. (2013). Faktor-faktor yang memengaruhi minat berwirausaha pada Mahasiswa Program Studi Pendidikan Ekonomi FKIP UNS. Jupe-Jurnal Pendidikan Ekonomi, 2(1).

Rustika, I. M. (2012). Efikasi diri: tinjauan teori Albert Bandura. Buletin Psikologi, 20(1-2), 18-25.

Sumarwan, Ujang. 2003. Perilaku Konsumen Teori dan Penerapannya dalam Pemasaran. Bogor: PT. Ghalia Indonesia.

Suroto, B., Novita, N., Pailis, E. A., Waldelmi, I., \& Fatkhurahman, F. (2017). Metode Penelitian 
Tindakan Solusi Bagi Masalah Sosial. Jurnal Diklat Review, 1(1), 25-28.

Suseno, M. N. M. (2012). Pengaruh pelatihan komunikasi interpersonal terhadap efikasi diri sebagai pelatih pada mahasiswa. Jurnal Intervensi Psikologi, 1(1).

Walgito, Bimo. 2003. Pengantar Psikologi Umum. Yogyakarta: Andi Offset.

Wijaya, T. (2009). Kajian model empiris perilaku berwirausaha UKM DIY dan Jawa Tengah. Jurnal manajemen dan kewirausahaan, 10(2), 93-104.

Wulandari, S. (2013). Pengaruh efikasi diri terhadap minat berwirausaha pada siswa kelas XII di SMK Negeri 1 Surabaya. Jurnal Pendidikan Tata Niaga (JPTN), 1(1). 